\title{
Progressive hemifacial atrophy
}

INSERM

\section{Source}

INSERM. (1999). Orphanet: an online rare disease and orphan drug data base.

Progressive hemifacial atrophy. ORPHA:1214

Progressive hemifacial atrophy (PHA) is a rare acquired disorder, characterized by unilateral slowly progressive atrophy of the skin and soft tissues of half of the face leading to a sunken appearance. Muscles, cartilage and the underlying bony structures may also be involved. 